\title{
EFFECT OF ADDITION OF MOLASSES AND PERIOD OF PRESERVATION ON PHYSICAL AND NUTRITIONAL PROPERTIES OF MAIZE STOVER SILAGE
}

\author{
A. B. M. R. Bostami' ${ }^{1}$ R. I. Khan ${ }^{2}$, M. R. Amin ${ }^{2}$, N. R. Sarker ${ }^{1}$, \\ S. Pervage ${ }^{1}$ and K. Hasan ${ }^{1}$
}

\begin{abstract}
An experiment was undertaken to determine the physical and nutritional properties, in vitro digestibility and metabolizable energy of maize stover ensiled with different levels of molasses at three different ensiling times (45, 90 and 135 days). Maize stover was collected from field immediately after harvesting the corn, chopped and were preserved in plastic containers under normal condition and were treated as control ( $\left.\mathrm{T}_{0}\right)$ (sample only), sample ensiled without additives $\left(\mathrm{T}_{1}\right)$, sample with addition of $20 \%$ water $\left(\mathrm{T}_{2}\right)$, sample with addition of $20 \%$ water and $2 \%$ molasses $\left(T_{3}\right)$, samples with addition of $20 \%$ water and $4 \%$ molasses $\left(\mathrm{T}_{4}\right)$, sample with addition of $20 \%$ water and $6 \%$ molasses $\left(\mathrm{T}_{5}\right)$. After completion of each ensiled period, physical and nutritional properties, in-vitro digestibility and metabolizable energy were determined. The result reveals that physical properties (color, smell, softness and fungal growth) of maize stover were improved in molasses treatments. It was also improved with increasing the ensiling time from 45 to 135 days. Among the treatments $\mathrm{T}_{4}$ was found best, as there were no fungal growth. The crude protein $(\mathrm{CP})$ content of maize stover was increased $(\mathrm{P}<0.01)$ and the dry matter $(\mathrm{DM})$, organic matter $(\mathrm{OM})$ and crude fibre $(\mathrm{CF})$ contents were decreased $(\mathrm{P}<0.01)$ after ensiling and addition of molasses. The highest DM, OM and CF content was found to be $72.33,87.70$ and $37.08 \%$ in $\mathrm{T}_{0}$ and highest $\mathrm{CP}$ was found to be $10.67 \%$ in $\mathrm{T}_{4}$ but the lowest DM, OM, CF and CP was found to be $63.17 \%$ in $\mathrm{T}_{2}, 82.68 \%$ in $\mathrm{T}_{3}, 28.18 \%$ in $\mathrm{T}_{5}$ and $6.28 \%$ in $\mathrm{T}_{0}$. The DM, OM, CP and CF contents were similar $(\mathrm{P}>0.01)$ at different ensiling time (45 to 135 days). The OMD (organic matter digestibility) and $\mathrm{ME}$ (metabolizable energy) contents were increased by ensiling with molasses. The highest OMD and ME values were observed in treatment $\mathrm{T}_{4}$ which were $42.01 \%$ and $6.50 \mathrm{MJ} / \mathrm{kg}$ DM, respectively. Therefore, it can be concluded that the addition of molasses improved the physical and nutritional properties and preservation capacity of maize stover after 135 days of ensiling.
\end{abstract}

Key words : Maize stover, Ensiling, Physical and nutritional properties, In vitro digestibility

\section{Introduction}

Cultivation of maize is increasing as maize corn is using as the main ingredient of poultry feed and confectionaries and poultry farming is now the second largest industry in

\footnotetext{
${ }^{1}$ Scientific Officer, Bangladesh Livestock Research Institute, Savar, Dhaka-1341, Bangladesh

${ }^{2}$ Department of Animal Science, Bangladesh Agricultural University, Mymensingh-2202, Bangladesh
}

(Received : October 15, 2008) 
Bang. J. Anim. Sci. 2008, 37(2)

Bangladesh. There is huge production of maize stover which is about 25-30 ton/ha/year (Sarker et al., 2007). Maize stover has a higher crude protein content of about $6 \%$ and metabolizable energy (ME) value of about $9 \mathrm{MJ} / \mathrm{kg}$ DM (McDonald et al., 1995) than rice straw though maize stover is characterized by a low protein, high fibre content and structurally too hard compared to other high quality roughages. The stover may be chopped, ensiled and fed in a similar way to maize silage (McDonald et al., 1995). Different physicochemical and biological processing of maize stover may increase its nutritional and preservative quality and make it palatable to ruminants. Molasses is suitable for feeding ruminants as it is wholesome, easy to use, effective, palatable, dust free, promote fermentation and contain some concentrated nutrients. It helps in facilitating the natural preservation by lowering the $\mathrm{pH}$ and producing lactic acid bacteria (Premier Molasses, 2006). Addition of molasses and ensiling of chopped maize stover can be the effective means of improving the nutritive value. Considering the above evidence the present experiment was under taken to investigate the effect of addition of molasses and ensiling time on physical properties, nutritional properties, in vitro digestibility and metabolizable energy contents of maize stover silage.

\section{Materials and Methods}

The experiment was conducted in the Laboratory of the Department of Animal Science, Faculty of Animal Husbandry, Bangladesh Agricultural University, Mymensingh, Bangladesh. Maize stover was chopped, ensiled with $0,2,4$ and $6 \%$ molasses in addition to $20 \%$ water and was kept into airtight plastic container for period of 45, 90 and 135 days. At three intervals of 45, 90 and 135 days, the preserved samples were observed and subsampled for physical observation, chemical analysis and in vitro digestibility determination.

\section{Collection of the experimental materials}

The maize stovers were collected from the field of Sherpur upazila of Bogra district just after collection of corn cobs. Commercial cane molasses were purchased from local market.

\section{Processing and preservation of the materials}

After collection, maize stover samples were chopped into 3-4 cm length. The chopped maize stover $(3 \mathrm{~kg}$ ) was placed in a plastic bowl, mixed well with $20 \%$ water and 2,4 and $6 \%$ molasses. The properly mixed samples were poured into previously leveled container, pressed, squeezed sufficiently to make airtight by hand pressure and tightly closed the cover. The ensiled samples were then kept at room temperature $\left(28\right.$ to $\left.32^{\circ} \mathrm{C}\right)$ for 45,90 and 135 days. 
The treatment groups were as follows :

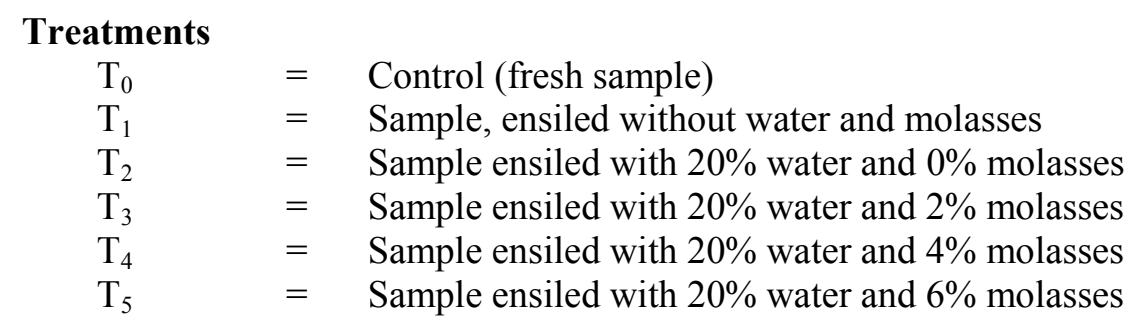

\section{Observation and collection of samples}

The ensiled sample of the each plastic container was opened after 45, 90 and 135 days respectively. The physical changes of all ensiled samples were observed and documented. Fungus was detected with visual estimation. During the observation $100 \mathrm{~g}$ of sample was taken out from each replication for chemical analysis. The DM and OM content was measured on fresh basis. All the samples were air dried and ground with the help of grinding machine of about $1 \mathrm{~mm}$ in diameter for chemical analysis and in vitro digestibility technique.

\section{Chemical analysis}

Untreated and treated maize stover samples were analyzed for DM, Ash, OM, CP and CF according to the methods of AOAC (1984).

\section{Measurement of in vitro gas production (IVGP), organic matter digestibility (OMD) and metabolizable energy (ME) \\ Hohenheim gas test was used to measure in vitro gas production (IVGP), to calculate the organic matter digestibility (OMD) and metabolizable energy (ME) content of maize stover sample using hay as standard and blank was used for correction of gas measurement. The method was based on the in vitro gas production technique described by Menke et al. (1979) and Menke and Steingass (1988).}

\section{Statistical analysis}

The data of proximate components and in vitro digestibility were analyzed using SPSS statistical programme (SPSS75 version), using two factorial experimental design and means were compared using Duncan's Multiple Range Test (DMRT).

\section{Results and Discussion}

\section{Physical properties of ensiled maize stover}

The physical properties of untreated and treated and ensiled maize stover at different periods were shown in Table 1 . Result indicates that ensiled maize stover $\left(T_{1}\right.$ and $\left.T_{2}\right)$ without molasses had unacceptable colour, smell, softness and there was much fungal growth. Molasses treatments $\left(T_{3}, T_{4}\right.$ and $\left.T_{5}\right)$ had good colour, smell and softness but some fungal 
Bang. J. Anim. Sci. 2008, 37(2)

growth was observed with $\mathrm{T}_{3}$ and $\mathrm{T}_{5}$. In the present experiment brown colour was increased with increasing the level of molasses from 2 to $6 \%$. Otieno et al. (1986) also found that maize stover ensiled with 5\% molasses produced brownish colour silage and had typical silage smell. Fermentation with addition of molasses indicates good silage quality as well as colour, smell and no fungal growth (Snijders and Wouters, 2004). Ensiling with 3, 6 and 9\% molasses produced acceptable colour of brownish yellow or yellow brown and typical smell but with 6 and 9\% molasses there were some spoilage due to fungal growth (Man and Wiktorsson, 2003). In the present experiment, based on the colour, smell and fungus appearance, the silages considered to be acceptable with $4 \%$ level of molasses than those of 2 and $6 \%$ levels. It was supported by Man and Wiktorsson, (2003) who reported that the low level of molasses $(3 \%)$ was better than the high level (6 and 9\%) of molasses in terms of colour, softness and fungal growth. Snijders and Wouters (2004) reported that, addition of $3 \%$ molasses obtained good quality silage. The level of 5\% molasses may be sufficient for producing good quality silage (Thanh et al., 2000). The presence of fungus in silage is undesirable because it uses silage nutrients and toxins are sometimes produced (Man and Wiktorsson, 2003).

Table 1. Effect of different treatments and ensiling durations on the physical properties of maize stover

\begin{tabular}{|l|c|c|c|c|c|c|c|}
\hline \multirow{2}{*}{ Parameters } & \multirow{2}{*}{ Days } & \multicolumn{6}{|c|}{ Treatments } \\
\cline { 3 - 8 } Colour & & $\mathbf{T}_{\mathbf{0}}$ & $\mathbf{T}_{\mathbf{1}}$ & $\mathbf{T}_{\mathbf{2}}$ & $\mathbf{T}_{\mathbf{3}}$ & $\mathbf{T}_{\mathbf{4}}$ & $\mathbf{T}_{\mathbf{5}}$ \\
& 45 & Greenish & Blackish & Blackish & Grey brown & Brownish & Brownish \\
& 90 & Grey & Black & Blackish & Brownish & Brownish & Brownish \\
& 135 & Grey & Black & Blackish & Brownish & Brownish yellow & Blackish \\
\hline \multirow{4}{*}{ Smell } & 45 & Natural smell & Bad & Bad & Moderately good & Good & Good \\
& 90 & Natural smell & Bad & Bad & Moderately Good & Good & Good \\
& 135 & Natural smell & Bad & Bad & Good & Very Good & Good \\
\hline \multirow{4}{*}{ Softness } & 45 & Hard & Hard & Hard & Hard & Moderately soft & Moderately soft \\
& 90 & Hard & Hard & Hard & Moderately soft & Soft & Soft \\
& 135 & Hard & Hard & Hard & Soft & Soft & Soft \\
\hline \multirow{3}{*}{ Fungus } & 45 & Absent & Present & Present & Absent & Absent & Present \\
& 90 & Absent & Present & Present & Present & Absent & Present \\
& 135 & Absent & Present & Present & Present & Absent & Present \\
\hline
\end{tabular}

${ }^{\#} \mathrm{~T}_{0}=$ Untreated and unensiled, $\mathrm{T}_{1}=$ Untreated and ensiled, $\mathrm{T}_{2}=$ Ensiled with $20 \%$ water, $\mathrm{T}_{3}=\mathrm{T}_{2}+2 \%$ molasses, $\mathrm{T}_{3}=\mathrm{T}_{2}+4 \%$ molasses $\mathrm{T}_{3}=\mathrm{T}_{2}+6 \%$ molasses. Hard indicating not acceptable by ruminants by (cattle, sheep, goat etc). Soft indicating accepted by ruminants (cattle, sheep, goat etc)

In the present experiment fungal growth in some samples were increased with increasing ensiling time from 45 to 135 days, but the colour, smell and softness of maize stover were improved with increasing the ensiling duration when specially molasses $\left(T_{3}, T_{4}\right.$ and $\left.T_{5}\right)$ was added. Though fungus was found in 2 and $6 \%$ molasses treatments, in that case fungal growth increased with increasing ensiling period from 45 to 135 days. Man and Wiktorsson, (2003) found that ensiling of maize stover with molasses increased the degree of brown 
colour with increasing ensiling time (from 2 to 4 months) in the silage but fungus was observed after 4 months of ensiling. Two months of ensiling with 5\% molasses treated maize stover results a good appearance (brownish colour) and typical silage smell (Otieno et al., 1986). Changing in colour and improvement in brown colour from 20 to 50 days was also observed by Hiep and Man (2003) but fungal growth was increased with increasing the ensiling time. Spoiling increased with the long-term storage and with the high level of molasses (Man and Wiktorsson, 2003). Ensiling time may have effects on increasing in fungal growth (Petersson, 1988).

\section{Nutritional properties}

Effect of different treatments and ensiling time on the composition of maize stover is shown in Table 2. The highest DM content was $(72.33 \%)$ found in untreated $\left(\mathrm{T}_{0}\right)$ and lowest $(63.17 \%)$ in $20 \%$ water treated $\left(\mathrm{T}_{2}\right)$ maize stover $(\mathrm{P}<0.01)$. The DM content was decreased significantly $(\mathrm{P}<0.05)$ with the addition of water and molasses $\left(\mathrm{T}_{2}, \mathrm{~T}_{3}, \mathrm{~T}_{4}\right.$ and $\left.\mathrm{T}_{5}\right)$ treated maize stover. The reason of decreasing the DM content in the present study may be due to addition of water, to properly mix the molasses and for proper compactness of ensiling. Nour, (1990) reported that ensiling with 3\% molasses reduced the DM content. The DM content loss also found by Otieno et al. (1986); Hiep and Man, (2003) and Man and Wiktorsson (2003). Among the molasses treatments $\left(T_{3}, T_{4}\right.$ and $\left.T_{5}\right)$ DM content was increased from 64.22 to $66.78 \%$ with increasing the level of molasses from 2 to $6 \%$ $(\mathrm{P}<0.01)$. The findings were similar to the trend of DM level which was reported by Man and Wiktorsson, (2003) where DM content was increased from 26.7 to $27.7 \%$ with 0 to $9 \%$ molasses, from 20.83 to $22.77 \%$ with $5 \%$ molasses (Otieno et al., 1986) and from 26.5 to $28.1 \%$ with $4 \%$ molasses (Hiep and Man, 2003) in maize stover. In the present study, it was observed that DM content was decreased with ensiling time from 67.41 to $66.45 \%$ with the increase of duration from 45 to 135 days $(\mathrm{P}>0.01)$. There were some experiments where in the ensiled maize stover, the DM content decreased from 22.58 to $20.83 \%$ (Otieno et al., 1986), from 29.1 to $26.5 \%$ (Hiep and Man, 2003), from 28.0 to $26.4 \%$, (Man and Wiktorsson, 2003) with increasing the ensiling time.

The OM content was highest $(87.70 \%)$ in the untreated $\left(\mathrm{T}_{0}\right)$ and lowest $(82.68 \%)$ in $2 \%$ molasses treated $\left(\mathrm{T}_{3}\right)$ maize stover $(\mathrm{P}<0.01)$. In the present experiment, OM content was decreased $(\mathrm{P}<0.05)$ from $87.70 \%\left(\mathrm{~T}_{0}\right)$ to $82.68 \%\left(\mathrm{~T}_{3}\right)$ after ensiling with molasses (Table 2$)$. Similar observation was reported by Hiep and Man (2003) where the OM content reduced from 91.0 to $88.90 \%$ with ' 0 ' to $4 \%$ molasses in maize stover silage. The OM content in different ensiling time 45,90 and 135 days were $84.79,84.18$ and $84.97 \%$, respectively. The present study indicates that there was no effect of ensiling time on the OM content $(\mathrm{P}>0.01)$. Man and Wiktorsson, (2003) reported that OM content is reduced in cassava top silage with increasing ensiling time. Due to ensiling time in the presence or absence of additives, organic matter may be increased or decreased, which may be depends on different factors such as biochemical or microbial reactions during ensiling period. 
Bang. J. Anim. Sci. 2008, 37(2)

Table 2. Effect of different treatments and different ensiling time on the composition of maize stover (\% on DM basis)

\begin{tabular}{|c|c|c|c|c|c|c|c|c|c|c|}
\hline \multirow{2}{*}{ Parameters } & \multirow{2}{*}{ Days } & \multicolumn{6}{|c|}{ Treatments $^{\#}$} & \multirow{2}{*}{ Mean } & \multirow{2}{*}{ SEM } & \multirow{2}{*}{$\begin{array}{c}\text { Level of } \\
\text { Sig. }\end{array}$} \\
\hline & & $\mathbf{T}_{\mathbf{0}}$ & $T_{1}$ & $T_{2}$ & $\mathbf{T}_{3}$ & $\mathbf{T}_{4}$ & $T_{5}$ & & & \\
\hline \multirow{5}{*}{$\mathrm{DM}$} & 45 & 72.40 & 71.11 & 64.69 & 63.88 & 65.90 & 66.50 & $67.41^{\mathrm{a}}$ & 1.43 & $\mathrm{NS}$ \\
\hline & 90 & 72.94 & 69.77 & 62.44 & 64.38 & 65.42 & 66.95 & $66.98^{\mathrm{a}}$ & 1.56 & NS \\
\hline & 135 & 71.66 & 67.84 & 62.38 & 64.42 & 65.54 & 66.88 & $66.45^{\mathrm{a}}$ & 1.30 & NS \\
\hline & Mean & $72.33^{\mathrm{a}}$ & $69.57^{\mathrm{b}}$ & $63.17^{\mathrm{e}}$ & $64.22^{\mathrm{de}}$ & $65.62^{\mathrm{cd}}$ & $66.78^{c}$ & - & - & \\
\hline & SEM & 0.37 & 0.95 & 0.76 & 0.17 & 0.14 & 0.14 & - & - & \\
\hline \multicolumn{2}{|l|}{ Level of sig. } & $* *$ & $* *$ & $* *$ & $* *$ & $* *$ & $* *$ & & & \\
\hline \multirow{5}{*}{$\mathrm{OM}$} & 45 & 87.31 & 86.52 & 84.28 & 81.76 & 84.75 & 82.39 & $84.50^{\mathrm{a}}$ & 0.90 & NS \\
\hline & 90 & 87.07 & 84.37 & 83.39 & 80.87 & 82.32 & 84.29 & $83.72^{\mathrm{a}}$ & 0.86 & NS \\
\hline & 135 & 88.74 & 85.36 & 83.99 & 85.42 & 81.37 & 85.13 & $85.00^{a}$ & 0.98 & NS \\
\hline & Mean & $87.70^{\mathrm{a}}$ & $85.42^{\mathrm{ab}}$ & $83.89^{\mathrm{b}}$ & $82.68^{\mathrm{b}}$ & $82.81^{\mathrm{b}}$ & $83.94^{\mathrm{b}}$ & - & - & \\
\hline & SEM & 0.43 & 0.65 & 0.42 & 0.77 & 0.63 & 0.57 & - & - & \\
\hline \multicolumn{2}{|l|}{ Level of sig. } & $* *$ & $* *$ & $* *$ & $* *$ & $* *$ & $* *$ & & & \\
\hline \multirow{5}{*}{$\mathrm{CP}$} & 45 & 6.34 & 6.31 & 7.15 & 8.58 & 8.48 & 9.50 & $7.73^{b}$ & 0.54 & NS \\
\hline & 90 & 6.24 & 6.55 & 8.34 & 8.40 & 11.73 & 11.54 & $8.8^{\mathrm{a}}$ & 0.97 & NS \\
\hline & 135 & 6.25 & 7.12 & 7.47 & 9.16 & 12.99 & 8.49 & $8.58^{\mathrm{a}}$ & 0.98 & NS \\
\hline & Mean & $6.28^{\mathrm{e}}$ & $6.66^{\text {ed }}$ & $7.65^{\text {bcd }}$ & $8.71^{\text {bc }}$ & $11.07^{\mathrm{a}}$ & $9.84^{\mathrm{a} b}$ & - & - & \\
\hline & SEM & 0.07 & 0.13 & 0.23 & 0.21 & 0.81 & 0.50 & - & - & \\
\hline \multicolumn{2}{|l|}{ Level of sig. } & $* *$ & $* *$ & $* *$ & $* *$ & $* *$ & $* *$ & & & \\
\hline \multirow{5}{*}{$\mathrm{CF}$} & 45 & 36.73 & 35.06 & 33.85 & 31.51 & 27.38 & 28.22 & $32.13^{\mathrm{a}}$ & 1.54 & NS \\
\hline & 90 & 37.64 & 34.41 & 33.36 & 32.27 & 30.38 & 27.52 & $32.60^{\mathrm{a}}$ & 1.42 & NS \\
\hline & 135 & 36.88 & 36.15 & 32.44 & 28.95 & 27.08 & 28.79 & $31.72^{\mathrm{a}}$ & 1.68 & NS \\
\hline & Mean & $37.08^{\mathrm{a}}$ & $35.21^{\mathrm{ab}}$ & $33.22^{\mathrm{b}}$ & $30.91^{\mathrm{c}}$ & $28.28^{\mathrm{d}}$ & $28.18^{\mathrm{d}}$ & - & - & \\
\hline & SEM & 0.29 & 0.32 & 0.38 & 0.69 & 0.70 & 0.41 & - & - & \\
\hline \multicolumn{2}{|l|}{ Level of sig. } & $* *$ & $* *$ & $* *$ & $* *$ & $* *$ & $* *$ & & & \\
\hline
\end{tabular}

${ }^{\#} \mathrm{~T}_{0}=$ Untreated and unensiled, $\mathrm{T}_{1}=$ Untreated and ensiled, $\mathrm{T}_{2}=$ Ensiled with $20 \%$ water, $\mathrm{T}_{3}=\mathrm{T}_{2}+2 \%$ molasses, $\mathrm{T}_{3}=\mathrm{T}_{2}+4 \%$ molasses $\mathrm{T}_{3}=\mathrm{T}_{2}+6 \%$ molasses

Values in superscripts within row and column are significantly different $(\mathrm{P}<0.05)$

NS $=$ Non-significant. ${ }^{*}$, Significant at $1 \%$ level

The CP content was highest $(10.67 \%)$ in $4 \%$ molasses treated $\left(\mathrm{T}_{4}\right)$ maize stover $(\mathrm{P}<0.01)$ followed by $9.84,8.71,7.65,6.66$ and $6.28 \% \operatorname{inT}_{5}, \mathrm{~T}_{3}, \mathrm{~T}_{2}, \mathrm{~T}_{1}$ and $\mathrm{T}_{0}$ of maize stover. It was observed that the CP content was highest in the $4 \%$ molasses treated $\left(\mathrm{T}_{4}\right)$ maize stover (10.67\%) followed by $\mathrm{T}_{5}, \mathrm{~T}_{3}, \mathrm{~T}_{2}, \mathrm{~T}_{1}$ and $\mathrm{T}_{0}(\mathrm{P}<0.01)$. So, the CP content increased from 6.28 to $10.67 \%$ in molasses treatment $\left(\mathrm{T}_{4}\right)$. Similar results also found by some researchers. Lanari et al. (1987) reported that molasses treatment increases the CP content of maize stover. Andrighelto et al. (1988) found the result that addition of liquid residue derived from molasses of $100-\mathrm{kg} / \mathrm{t}$ silage increase the CP content from 7.9 to $11.3 \%$. Ensiling with $1.5 \%$ molasses increase of CP content from 4.6 to $5.0 \%$ (Chauhan.,1985) and from 6.08 to $6.85 \%$ in maize stover silage (Otieno et al. (1986). Lee, et al. (1986) found that addition of energy source from $0-30 \%$ increased the CP content from 7.9 to $13.6 \%$ in maize stover ensiling. In the present experiment the $\mathrm{CP}$ content increment in the molasses treated may be due to the readily available energy from the molasses, which was used by the microorganism for their 
growth and increased microbial protein in the silage. Microbial nitrogen supply increased with increasing the supply of nitrogen, fermentable carbohydrate, sulfur and probably the other essential nutrients (Tolera and Sundstol, 2000), where molasses may serve the major supply of these essential nutrients. The magnitude of increase varies according to factors such as the nature of the material, the environment and the treatment process (Hiep and Man, 2003). The CP content increased with increasing the ensiling time during the present study $(\mathrm{P}>0.01)$. Parigi-Bini et al. (1987) reported that ensiling time with molasses treatment increased the CP content of maize stover, which was also supported by Lanari et al. (1987). The CP content increased with increasing ensiling time (Man and Wiktorsson, 2003 and Snijders et al., 2004) and with molasses increament (Snijders and Wouters, 2004).

The CF content was highest (37.08\%) in untreated $\left(\mathrm{T}_{0}\right)$ and lowest $(28.18 \%)$ in $6 \%$ molasses treated $\left(\mathrm{T}_{5}\right)$ maize stover $(\mathrm{P}<0.01)$. It was observed that in the present experiment the value of CF was significantly $(P<0.01)$ decreased in the treatments $\left(T_{1}\right.$ to $\left.T_{5}\right)$ of maize stover. The CF content of the 2, 4 and $6 \%$ molasses treated $\left(\mathrm{T}_{3}, \mathrm{~T}_{4}\right.$ and $\left.\mathrm{T}_{5}\right)$ maize stover was statistically similar, $(\mathrm{P}>0.05)$. The reason of decrease of $\mathrm{CF}$ content may be due to addition of water in the treatment groups. The findings were supported by Skultety et al. (1991) who reported that CF might be decreased with addition of water. In the present experiment CF content was decreased from 29.46 to $28.74 \%$ with increasing the ensiling time from 45 to 135 days but statistically not significant ( $\mathrm{P}>0.01)$. Similar result was observed by Hiep and Man (2003) where they reported that, the fibre content of maize stover reduced from 70.7 to $65.3 \%$ due to ensiling time. Ensiling time reduce the $\mathrm{CF}$ content of maize stover with water and molasses (Lanari et al., 1987). Decrease of CF content with increasing ensiling time in maize stover, sugarcane tops, sorghum stover was also found by Otieno et al., (1986).

It was revealed that the $\mathrm{DM}, \mathrm{OM}$ and $\mathrm{CF}$ content was decreased by $12.66,4.34$ and $24 \%$, respectively, where the CP content was increased by $69.90 \%$ or 1.7 times $(\mathrm{P}<0.01)$ by ensiling with $4 \%$ molasses. It was also observed that, the change in the DM, OM, CP and CF content were not significant $(\mathrm{P}>0.01)$ with increasing the ensiling time from 45 to 135 days.

\section{In-vitro OMD and ME}

The in vitro organic matter digestibility (OMD) and metabolizable energy (ME) contents after different treatments and ensiling of maize stover was presented in Table 3 . The predicted OMD was $(42.01 \%)$ found highest $(\mathrm{P}<0.01)$ in $4 \%$ molasses treatment $\left(\mathrm{T}_{4}\right)$ followed by $T_{5}, T_{3}, T_{2}, T_{1}$, and $T_{0}$, respectively. In the present experiment ME content was increased significantly $(\mathrm{P}<0.05)$ with treatment and ensiling. Highest $\mathrm{ME}$ content was 6.50 $\mathrm{MJ} / \mathrm{kg} \mathrm{DM}$ in the $4 \%$ molasses treatment $\left(\mathrm{T}_{4}\right)$ followed by $\mathrm{T}_{5}, \mathrm{~T}_{3}, \mathrm{~T}_{2}, \mathrm{~T}_{1}$, and $\mathrm{T}_{0}$, respectively. It was revealed that the OMD and ME content were increased by, 105, 38 and $44 \%$, respectively. Also, it was revealed that the OMD and ME content were significantly increased with increasing the ensiling time $(\mathrm{P}<0.05)$. Hiep and Man (2003) observed that molasses treatment and ensiling increase $(\mathrm{P}<0.05)$ the predicted OMD of maize stalks from 63.7 to $70.2 \%$ with $4 \%$ molasses level. Molasses treatment increased the predicted ME 
Bang. J. Anim. Sci. 2008, 37(2)

content was also observed by Otieno et al., 1986; Lanari et al., 1987 and Nour, 1990. Molasses as the energy source may increase the ME content in maize stover silage.

Table 3. In vitro organic matter digestibility (OMD) and metabolizable energy (ME) contents in maize stover after different treatments and ensiling

\begin{tabular}{|c|c|c|c|c|c|c|c|c|c|c|}
\hline \multirow{2}{*}{ Parameters } & \multirow{2}{*}{ Days } & \multicolumn{6}{|c|}{ Treatments } & \multirow{2}{*}{ Mean } & \multirow{2}{*}{ SEM } & \multirow{2}{*}{$\begin{array}{l}\text { Level of } \\
\text { Sig. }\end{array}$} \\
\hline & & $\mathbf{T}_{0}$ & $T_{1}$ & $\mathbf{T}_{2}$ & $\mathbf{T}_{3}$ & $\mathbf{T}_{4}$ & $\mathbf{T}_{5}$ & & & \\
\hline \multirow{5}{*}{ OMD } & 45 & 29.37 & 31.16 & 33.74 & 41.51 & 41.93 & 40.65 & $30.82^{c}$ & 0.61 & $* *$ \\
\hline & 90 & 30.28 & 33.26 & 36.12 & 40.66 & 44.11 & 41.57 & $37.63^{b}$ & 1.92 & $* *$ \\
\hline & 135 & 31.51 & 29.31 & 31.06 & 42.71 & 39.97 & 39.88 & $41.35^{\mathrm{a}}$ & 0.64 & $* *$ \\
\hline & Mean & $30.38^{c}$ & $31.24^{\mathrm{bc}}$ & $33.64^{\mathrm{b}}$ & $41.62^{\mathrm{a}}$ & $42.01^{\mathrm{a}}$ & $40.70^{\mathrm{a}}$ & & & \\
\hline & SEM & 0.62 & 1.14 & 1.46 & 0.60 & 1.20 & 0.49 & & & \\
\hline Level of sig. & & $* *$ & $* *$ & $* *$ & $* *$ & $* *$ & $* *$ & & & \\
\hline \multirow{5}{*}{ ME } & 45 & 4.34 & 4.62 & 5.56 & 6.17 & 6.24 & 6.03 & $4.78^{b}$ & 0.43 & $* *$ \\
\hline & 90 & 5.41 & 6.56 & 6.05 & 7.21 & 7.23 & 7.05 & $6.00^{\mathrm{a}}$ & 0.30 & $* *$ \\
\hline & 135 & 3.75 & 3.98 & 5.01 & 5.98 & 6.02 & 5.99 & $6.43^{\mathrm{a}}$ & 0.23 & $* *$ \\
\hline & Mean & $4.50^{\mathrm{d}}$ & $5.05^{\mathrm{cd}}$ & $5.54^{\mathrm{cd}}$ & $6.45^{\mathrm{abc}}$ & $6.50^{\mathrm{abc}}$ & $6.36^{\mathrm{bc}}$ & & & \\
\hline & SEM & 0.49 & 0.78 & 0.30 & 0.38 & 0.37 & 0.35 & & & \\
\hline
\end{tabular}

${ }^{\#} \mathrm{~T}_{0}=$ Untreated and unensiled, $\mathrm{T}_{1}=$ Untreated and ensiled, $\mathrm{T}_{2}=$ Ensiled with $20 \%$ water, $\mathrm{T}_{3}=\mathrm{T}_{2}+2 \%$ molasses, $\mathrm{T}_{3}=\mathrm{T}_{2}+4 \%$ molasses $\mathrm{T}_{3}=\mathrm{T}_{2}+6 \%$ molasses

Values in superscripts within row and column are significantly different $(\mathrm{P}<0.05)$

$*$, Significant at $5 \%$ level, $* *$, Significant at $1 \%$ level.

\section{Conclusion}

Results indicated that addition of molasses helps to improve the physical and nutritional properties and preservation capacity of maize stover. Addition of $4 \%$ molasses and 90 days ensiling of maize stover showed good color, smell, softness, nutritional quality and longer preservation capacity. Therefore, Maize stover may be ensiled for 90 days by adding $4 \%$ molasses and $20 \%$ water. However, further investigation is needed to conduct in vivo feeding trial with maize stover silage using molasses to justify the present findings.

\section{Literature Cited}

Andrighetto, I., Bittante, G., Cavalli, R. and Daolio, S. 1988. Effect of harvesting system and the use of a liquid by-product obtained from molasses on maize stover silage. Zootecnica-eNutrizions Animale. 14(1) : 35-44.

AOAC. 1984. Official Methods of Analysis (13 ${ }^{\text {th }}$ Edn). Association of Official Analytical Chemistry, Washington DC, USA.

Chauhan, T. R. 1985. Comparative nutritive value of winter-maize stover as hay and silage made with or without enrichment. Department Animal Sciences. Punjab Agricultural Univ., Ludhiana141004, India. Indian J Anim. Nutri. 2(2) : 75-78. 
Hiep, N. V. and Man, N. V. 2003. Dairy cattle feed from stover derived from mature and immature maize crops in small holder crop-livestock production systems in Vietnam. University of Agriculture and Forestry, Thu Duc, Ho Chi Minh city, Vietnam. manmy@hcm.vnn.vn.

Lanari, D., Pinosa, M. and Tibaldi, E. 1987. Improvement of conservation and nutritive value of maize stover ensiled with molasses or beet pulp or preserved with ammonia in heaps, and feeding trials with growing heifers. Zootecnica-e-Nutrizione-Animale. 13 : 5, 483-497.

Lee, S. B., Chung, Y. H., Kang, S. W. , Lee, B. S. and Jung, K. K. 1986. Studies on the improving nutritive value of corn stover. 1. A study on the corn stover silage of different levels of rice bran and urea additions. Research Reports of the Rural Development Administration, Livestock and Veterinary, Korea Republic. 28 : 1, 27-31.

Man, N. and Wiktorsson, H. 2003. The effect of molasses on quality, feed intake and digestibility by heifers of silage made from cassava tops. Department of Animal Nutrition, UAF, Thu Duc, Ho Chi Minh City, Vietnam. Internet Collection.

McDonald, P., Edwards, R. A. and Greenhalgh, J. F. D. 1995. Animal Nutrition. $5^{\text {th }}$ edition. pp. $75-81$.

Menke, K. H., and Steingass, H. 1988. Estimation of energetic feed value obtained from chemical analysis and in vitro gas production using rumen fluid. Anim. Res. Develop. 28 : 7-55.

Menke, K. H., Raab, L., Salewski, A., Steingass, H., Fritz, D. and Schneider, W. 1979. The estimation of the digestibility and metabolizable energy (ME) content of ruminant feeding stuffs from the gas production when they are incubated with rumen liquor in-vitro. J. Agric. Sci., Cambodia, $93: 217-222$.

Nour, A. M. 1990. Utilization of rice straw on small farmer in Egypt. Department of Animal Production. Faculty of Agriculture, Alexandria University, Egypt. FAO Corporate Document Repository. Originate by: ILTI. pp. 75-81.

Otieno, K., Onim, J. F. M. and Mathuva, M. N. 1986. A gunny-bag ensiling technique for smallscale farmers in Western Kenya. Ministry of Livestock Department/SR-CRSP, Maseno, Kenya. Internet Collection.

Parigi-Bini, R., Volpato, M. R. Xiccato, G. and Cinetto, M. 1987. Research on the preparation, digestibility and utilization of maize stover silage and molasses in fattening bull calves. Zootecnica-e-Nutrizione-Animale. 13(2): 91-106.

Pertersson, K. 1988. Ensiling of forages, factors affecting silage fermentation and quality. Dissertation, Swedish Univ. Agri. Sci., report 179. Uppsala.

Premier Molasses. 2006. Farm use of molasses. Molasses as a silage preservative. Benefits of molasses. Internet Search.

Sarker, N. R., Hoque, K. S. and Aszduzzaman, M. 2007. On farm demonstration of processing, preservation and utilization of maize stover technology in some selected areas of Bangladesh. Proceedings. Research Review workshop, BLRI, Savar, Dhaka, 2007. (Some information collected by Personal Communication from BLRI).

Skultety, M., Skultetyova, N. and Bencova, E. 1991. Effect of different proportions of dry maize straw on fodder beet silage quality. Pol'nohospodarstvo. 37(7-8) : 648-654.

Snijders, P. J. M. and Wouters, A.P. 2004. Silage quality and losses due to ensiling of Napier grass, Columbus grass and Maize stover under small holder conditions in Kenya. FAO Electronic Conference on Tropical Silage. 
Bang. J. Anim. Sci. 2008, 37(2)

Thanh, V. T. K., Loc, N. T., Phuong, D. T. and Luu, P. T. 2000. Evaluation of ensiled groundnut leaves for fattening pigs. Hue college of Agriculture and Forestry. Hue University, Processing, Preservation and using cassava leaf silage for mong cai sows in central Vietnam. Page 1-5.

Tolera, A. and Sundstol, F. 2000. Supplementation of graded levels of Desmodium intortum hay to sheep feeding on maize stover harvested at three stages of maturity. 2. Rumen fermentation and nitrogen metabolism. Anim. Feed Sci. and Tech. 87(3-4) : 215-229. Ahmed, N. 1992. Problems and prospects of livestock in Bangladesh.In proceeding work of livestock Development project in Bangladesh. 16-18 July, BLRI. 1991 : 8-14.

Wongsrikao, W. and Wanapat, M. 1985. The effects of urea treatment of rice straw on the intake and live weight gain of buffaloes. In the utilization of Fibrous Agricultural Residues as Animal Feeds. pp. 81-85. ed. P. T. Doyole. International Development programme of Australian Universities and Colleges, Canberra, Australia. pp. 81-85. 